\title{
O EXERCÍCIO DA DISCRICIONARIEDADE ADMINISTRATIVA NO CONTEXTO DO ESTADO SOCIAL E DEMOCRÁTICO DE DIREITO: LIMITES E POSSIBILIDADES A PARTIR DA CONSTITUIÇÃO FEDERAL DE 1988
}

\author{
Adriano Aranão 1 \\ Renato Bernardi ${ }^{2}$
}

\begin{abstract}
Resumo: O presente artigo analisa as possibilidades e limites da discricionariedade administrativa no Estado Social e Democrático de Direito, propondo a releitura dos princípios da legalidade, da supremacia do interesse público e da igualdade perante a administração. Apresenta critérios distintivos entre ato administrativo vinculado e discricionário, além de discorrer sobre os parâmetros constitucionais e legais que devem nortear a decisão discricionária. Inspirando nas luzes pós-positivistas, a pesquisa conta com a revisão bibliográfica sobre o tema e, adotando o método dedutivo, busca aproximar os preceitos constitucionais da atuação discricionária do administrador público.
\end{abstract}

Palavras-chaves: Discricionariedade; Princípio da Legalidade; Administração Pública; Póspositivismo; Direitos Fundamentais.

\section{DISCRITIONARITY ADMINISTRATIVE EXERCISE IN SOCIAL AND RULE OF}

\section{LAW STATE CONTEXT: LIMITS AND POSSIBILITIES FROM 1988 FEDERAL CONSTITUTION}

\begin{abstract}
The current paper analyzes the possibilities and limits of administrative discretionary powers in Social and Democratic Rule of Law State, proposing a new reading of legality, public interest supremacy and equality principles before the administration. It presents the distinctive criteria between binded administrative and discretionary acts, besides enunciating constitutional and legal parameters that must conduct discretionary decision. Inspired on postpositivism lights, the research counts on bibliographical review about the theme and, adopting deductive method, it seeks to approach constitutional concepts of discretionary acting to the public administrator.
\end{abstract}

Keywords: Discretionary; Legality Principle; Public Administration; Post-positivism; Fundamental Rights.

\footnotetext{
${ }^{1}$ Doutorando em Ciências Jurídicas pela Universidade Estadual do Norte do Paraná (UENP), Coordenador do Curso de Direito das Faculdades Integradas de Ourinhos (FIO) e Oficial da Polícia Militar de São Paulo.

${ }^{2}$ Doutor em Direito pela PUC/SP. Professor efetivo dos cursos de Bacharelado, Mestrado e Doutorado, Coordenador de TCC e Membro da Comissão de Coordenação do Programa de Mestrado em Ciência Jurídica, todos da Faculdade de Direito do CCSA-UENP, Campus de Jacarezinho/PR. Coordenador Pedagógico do PROJURIS Estudos Jurídicos Ltda. Procurador do Estado de São Paulo desde 1994.
} 


\section{INTRODUÇÃO}

O presente artigo tem por objetivo analisar as possibilidades e limites do exercício da discricionariedade administrativa sob o contexto do Estado Social e Democrático de Direito instituído a partir da Constituição Federal de 1988.

As transformações operadas na compreensão do fenômeno jurídico a partir do pensamento pós-positivista produziram impactos profundos nas relações que permeiam entre o Estado e os indivíduos, exigindo a revisão de valores e práticas que orientam a atuação dos três Poderes da República.

O Poder Judiciário se desvencilhou das amarras que até então limitavam a sua atuação e hoje tem sido o grande protagonista na afirmação dos direitos fundamentais. O Juiz deixou de ser o "boca da lei” e assumiu papel de destaque neste novo cenário jurídico-social.

Enquanto isso, no mais das vezes, o administrador público ainda repousa na literalidade fria da lei o limite da sua atuação, transportando, seja por comodismo, medo ou incompreensão, para o século XXI o que foi idealizado para o século XVIII.

Destarte, a definição do papel a ser exercido pelo administrador público contemporâneo exige a compreensão do evolver histórico do Estado de Direito e, consequentemente, a releitura do princípio da legalidade e da sua relação com a discricionariedade administrativa, análise que será objeto do primeiro capítulo deste texto.

O segundo capítulo cuidará da distinção entre ato administrativo vinculado e ato administrativo discricionário e o terceiro capítulo apresentará critérios que podem contribuir para a identificação da discricionariedade conferida pelo legislador ao administrador público.

Por fim, o quarto capítulo apresentará os parâmetros constitucionais e legais para o exercício discricionário, revisitando temas como os princípios da supremacia do interesse público e do tratamento igualitário de todos os cidadãos pela administração pública.

Tendo como ponto de partida a complexidade do cotidiano contemporâneo e a necessidade de conexão entre teoria e prática, a pesquisa contará, sob as luzes pós-positivistas, com a revisão bibliográfica sobre o tema e, adotando o método dedutivo, buscará aproximar os preceitos constitucionais da atuação discricionária do administrador público. 


\section{O EVOLVER HISTÓRICO DO ESTADO DE DIREITO E SUAS RELAÇÕES COM} A DISCRICIONARIEDADE ADMINISTRATIVA

A maior ou menor amplitude da discricionariedade administrativa está diretamente associada ao evolver histórico do Estado de Direito e aos contornos então assumidos pelo princípio da legalidade.

Assim sendo, não há que se perquirir da discricionariedade administrativa sob a senda Estado Absoluto, vez que aí a Administração Pública não estava vinculada a qualquer tipo de lei que regesse a sua atuação, senão àquela proveniente do próprio monarca.

Pode-se, portanto, afirmar que a análise da discricionariedade administrativa somente se torna possível a partir da instauração do Estado de Direito e, consequentemente, da eclosão do princípio da legalidade como limite à atuação discricionária dos governantes, posto que “"[...] o Estado de Polícia [Absoluto] se apresenta como aquele Estado cuja administração se acha legalmente incondicionada, enquanto o Estado de Direito oferece uma administração condicionada legalmente." (DI PIETRO, 2007, p. 18)

Entretanto, mesmo no contexto do Estado de Direito, é necessário compreender as transformações paradigmáticas que, ao longo do tempo, alteraram os seus contornos e como tudo isto refletiu nas ideias de legalidade e de administração pública. Só assim será possível entender com maior rigor os limites e possibilidades do exercício discricionário, notadamente sob os holofotes do Estado Social e Democrático de Direito inaugurado pela Constituição Federal de 1988.

O administrador público moderno não pode olvidar da relevância da dinâmica histórica do princípio da legalidade e das suas relações com a atividade discricionária da Administração Pública, especialmente para que possa conduzir-se de modo a dar fiel cumprimento às missões que hoje lhe são outorgadas pela Constituição brasileira.

No Estado Liberal de Direito, que surgiu a partir dos movimentos revolucionários que permearam no século das luzes, o princípio da legalidade se traduzia pela ideia de que a administração podia fazer não só o que a lei expressamente autorizasse como também tudo aquilo que não proibisse, de modo que era lícito ao administrador público "[...] usar de sua discricionariedade, isto é, de sua livre autonomia, em todos aqueles pontos que a lei não regulou." (DI PIETRO, 2007, p. 27). 
Nesse sentido, o art. $5^{\circ}$ da Declaração dos Direitos do Homem e do Cidadão de 1789 proclamava que "a lei não proíbe senão as ações nocivas à sociedade. Tudo que não é vedado pela lei não pode ser obstado e ninguém pode ser constrangido a fazer o que ela não ordene.”

Ainda sob a senda do liberalismo, observa Manoel Gonçalves Ferreira Filho (apud DI PIETRO, 2007, p. 22), o princípio da legalidade pressupunha a igualdade de todos perante a lei e, portanto, afirmava a "[...] obrigatória uniformidade de tratamento dos casos iguais e, face negativa, a proibição de discriminações".

Lembre-se aqui que, na doutrina liberal, a igualdade é abstrata e, portanto, desconsidera as desigualdades substanciais existentes no mundo real. Desta forma, a vedação das discriminações, evidentemente sob a feição positiva, conduzia (e conduz) a flagrantes violações dos direitos fundamentais da pessoa humana.

Com efeito, pode-se afirmar que no Estado Liberal de Direito havia ampla margem para a atuação discricionária do administrador público, posto que, além de fazer tudo aquilo que a lei expressamente lhe autorizasse, poderia realizar tudo aquilo que não lhe era defeso por lei.

Já no Estado Social de Direito, que surgiu a partir da busca da igualdade material e da correlata efetivação dos direitos fundamentais a todos os seres humanos, o princípio da legalidade assume novos contornos, operando-se a substituição da vinculação negativa para a vinculação positiva do administrador público à lei e, com isto, reduziu-se o campo da atuação discricionária.

Explica Maria Sylvia Zanella Di Pietro (2007, p. 38) que, no Estado Social de Direito, A própria discricionariedade tem que ser compreendida como um poder limitado pela lei; deixou de existir aquela esfera de ação em que a Administração Pública age livremente; a discricionariedade passou a ser vista como um poder jurídico [e não mais político]. $\mathrm{O}$ anterior princípio de que a Administração pode fazer tudo o que não está proibido foi substituído por aquele segundo o qual ela só poder fazer o que a lei permite.

Entretanto, se a vinculação positiva do administrador público ao princípio da legalidade representou um avanço no controle dos arbítrios e desmandos estatais, posto que sujeitou toda atividade administrativa à estreita vinculação aos mandamentos legais, reduzindo o espaço discricionário do administrador público, há também um inegável retrocesso, decorrente das mudanças da própria noção de lei.

Sob os influxos das deformações impostas à doutrina positivista, a lei passou a ser compreendida apenas sob seu caráter formal. A lei válida e, portanto, obrigatória, assim era 


\section{O EXERCÍCIO DA DISCRICIONARIEDADE ADMINISTRATIVA NO CONTEXTO DO ESTADO SOCIAL E DEMOCRÁTICO DE DIREITO: LIMITES E POSSIBILIDADES A PARTIR DA CONSTITUIÇÃO FEDERAL DE 1988}

aceita simplesmente porque emanada da autoridade competente para a sua elaboração, sem qualquer perquirição da adequação das suas regras aos princípios de justiça material.

E este apego exacerbado ao formalismo legal, que desconsidera o caráter instrumental da lei em face dos valores constitucionalmente consagrados, ainda é muito presente no Brasil. Notadamente no seio da Administração Pública, é preciso evoluir e compreender que o Direito não se subsume no texto legislado. Este é apenas um (importante, sem dúvidas) dos instrumentos que integram o ordenamento jurídico brasileiro e, enfatize-se, deve ser aplicado de forma a efetivar os valores explícita ou implicitamente acolhidos pela Constituição Federal de 1988.

Reverberando esta compreensão, Maria Sylvia Zanella Di Pietro (2007, p. 14) leciona que

\footnotetext{
Quando a lei é vista dentro de um sistema lógico-jurídico, despido de qualquer conteúdo axiológico - como ocorreu com Kelsen e seus adeptos -, a discricionariedade administrativa resultará mais forte, porque a Administração Pública só tem que observar a lei em sem sentido formal, único aspecto também a ser considerado pelo Poder Judiciário. Quando, porém, à lei formal se acrescentam considerações axiológicas, amplia-se a possibilidade de controle judicial, porque, por essa via, poderão ser corrigidos os atos administrativos praticados com inobservância de certos valores adotados como dogmas em cada ordenamento jurídico.
}

Insista-se que não se está aqui defendendo que o administrador público pode negar o cumprimento da lei sob a alegação de que esta não se alinha aos mandamentos constitucionais. Esta missão não lhe foi deferida pela ordem constitucional cidadã de 1988.

O que se propugna é que, ao aplicar a lei, seja na prévia e necessária interpretação ou, posteriormente, na escolha discricionária dentre os caminhos juridicamente abertos, o administrador público atue de maneira atenta aos valores constitucionais que, retome-se, vinculam a atuação dos agentes dos três Poderes do Estado.

Trata-se da superação do Estado Legal e do advento do Estado Constitucional de Direito, com o que se pretende novamente vincular a ideia de lei à realização dos princípios de justiça acolhidos pela Constituição Federal de 1988 e de submeter a Administração Pública não apenas à lei em sentido formal, mas, para muito além, a todo o Direito, devendo assim atuar para a realização dos valores que o inspiram, centralizados na dignidade da pessoa humana.

E assim tem evoluído o Direito mundial. Na Alemanha, o art. $1^{\circ}$ da Constituição de 1949 afirma que os direitos fundamentais são diretamente aplicáveis para os Poderes Legislativo, Executivo e Judiciário e o $\$ 3^{\circ}$ do art. 20 destaca que "os poderes executivo e judicial obedecem à lei e ao direito". 
De igual modo, a Constituição Espanhola de 1978, em seu art. 103.1, estabelece que a Administração Pública deve atuar com vistas aos interesses gerais e com submissão plena à lei e ao Direito.

No Brasil, é lugar comum entre os estudiosos do Direito Administrativo a afirmação de que administrar é aplicar a lei de ofício e que, por isso, trata-se de atividade subordinada, de modo que

[...] enquanto na atividade privada pode-se fazer tudo o que não é proibido, na atividade administrativa só se pode fazer o que é permitido. Em outras palavras, não basta a simples relação de não-contradição, posto que, demais disso, exige-se ainda uma relação de subsunção. (MELLO, 2011, p. 968)

Desta forma, o exercício discricionário do administrador público somente há de ocorrer quando assim lhe for permitido pela lei e, ainda mais, deverá restringir-se aos limites e possibilidades por ela abertos.

Entretanto, o essencial é compreender que, como averbera Maria Sylvia Zanella Di Pietro (2007, p. 43), a partir da Constituição Federal de 1988, como corolário do Estado Social e Democrático de Direito aí inaugurado, toda atividade estatal está submetida à lei e ao Direito, de modo que

[...] a lei, no Estado de Direito, tem sentido formal, pelo fato de que emana do Poder Legislativo (ressalvadas algumas hipóteses excepcionais previstas na Constituição, como é o caso das leis delegadas e das medidas provisórias) e sentido também material, porque lhe cabe o papel de realizar os valores consagrados pela Constituição sob a forma de princípios fundamentais.

Destarte, pode-se afirmar que a exata compreensão do princípio da legalidade a que, nos termos do caput do art. 37 da Constituição Federal de 1988, está jungida a Administração Pública, é no sentido de que a atuação administrativa deve aplicar a lei e exercer a discricionariedade com vistas à efetivação dos princípios e valores constitucionais.

Afirmando esta percepção, Odete Medauar (2001, p. 145) esclarece que

A Constituição de 1988 determina que todos os entes e órgãos da Administração
obedeçam ao princípio da legalidade (caput do art. 37); a compreensão desse princípio
deve abranger a observância da lei formal, votada pelo Legislativo, e também dos
preceitos decorrentes de um Estado Democrático de Direito, que é o modo de ser do
Estado brasileiro, conforme reza do art. $1^{\circ}$, caput da Constituição; e ainda, deve incluir
a observância dos demais fundamentos e princípios de base constitucional.

Portanto, a adequação dos atos administrativos ao princípio da legalidade é de ser coincidente, no contexto do Estado Social e Democrático de Direito instituído pela Constituição Federal de 1988, com o valor da dignidade da pessoa humana e dos direitos fundamentais. 


\section{ATO ADMINISTRATIVO DISCRICIONÁRIO E ATO ADMINISTRATIVO VINCULADO}

Como atividade juridicamente condicionada, a administração pública deve atuar com absoluto respeito aos valores, princípios e regras constitucionais e legais.

Nesse sentido, Celso Antônio Bandeira de Mello (2011, p. 969), após anotar o pensamento de vários doutrinadores do Direito Administrativo, afirma que

A pinha de citações tiradas a lume encarece o caráter estritamente subordinado que à Administração calha em regime de tripartição do exercício do Poder. Sobretudo no Direito brasileiro este ditame aplica-se com especial vigor. Respaldam a assertiva notadamente os arts. $5^{\circ}$, II, 37 e 84, IV, da Constituição.

Entretanto, algumas vezes o legislador impõe amarras estreitas e firmes à atuação administrativa e, em outras oportunidades, outorga ao administrador público certo espaço de liberdade de decisão. Na primeira hipótese configura-se a alcunhada competência vinculada e, na segunda, a competência discricionária do agente estatal.

De acordo com Diógenes Gasparini (2009, p. 80), “[...] são vinculados os [atos] praticados pela Administração Pública sem a menor margem de liberdade. A Administração Pública edita-os sem qualquer avaliação subjetiva" e, pouco adiante, conclui que os atos administrativos levados a efeito no exercício da competência vinculada devem ser "[...] praticados conforme o único comportamento que a lei prescreve à Administração Pública. A lei prescreve, em princípio, se, quando e como deve a Administração Pública agir ou decidir.” (2009, p. 96)

Destarte, no exercício da competência vinculada não se abre ao administrador público qualquer possibilidade de análise subjetiva acerca da oportunidade e conveniência quanto à prática de determinado ato administrativo.

Trata-se de atividade de mera subsunção do fato à norma legal, não sendo lícito ao administrador questionar quanto à justiça ou injustiça do ato praticado. Não lhe é deferida qualquer possibilidade de valoração em face do ato a ser praticado. Ocorrido o fato descrito na hipótese legal como deflagrador de determinada consequência jurídica, não resta ao administrador outra opção senão a de efetivá-la.

De outro lado, os atos levados a termo no exercício da competência discricionária são praticados pela Administração Pública “[...] com certa margem de liberdade. A Administração edita-os depois de uma avaliação subjetiva.” (GASPARINI, 2009, p. 80) 
Ao conferir ao administrador público a competência discricionária, o legislador lhe possibilita que, diante de determinado fato legalmente previsto, decida, segundo critérios de conveniência e oportunidade, quanto à medida a ser adotada no caso concreto.

Vale anotar que, segundo Diógenes Gasparini (2009, p. 97),

Há conveniência sempre que o ato interessa, convêm ou satisfaz ao interesse público. Há oportunidade quando o ato é praticado no momento adequado à satisfação do interesse público. [...] A oportunidade diz respeito com o momento da prática do ato. [...] A conveniência refere-se à utilidade do ato.

A opção legislativa pela outorga da competência discricionária ao administrador público costuma ser alicerçada pela doutrina nas seguintes justificativas: (i) deliberado intento legal de conferir à Administração certa liberdade para decidir diante dos multifacetários casos concretos; (ii) impossibilidade material do legislador de prever todas as formas de materialização de um fato administrativo e suas adequadas soluções no texto legal, o que levalhe a recorrer a fórmulas mais flexíveis; e (iii) inviabilidade jurídica da subtração da discricionariedade em face do sistema de tripartição do poder, pois, ao contrário, o legislador deixaria o campo dos tipos abstratos, próprio da atividade legislativa, para a individualização concreta, atividade afeta ao Poder Executivo. (MELLO, 2011, p. 973)

De qualquer forma, seja qual for a justificativa aclamada para fundamentar a concessão legal da discricionariedade ao administrador público, o mais relevante é que trata-se de uma "[...] faculdade conscientemente criada em favor e em benefício da gestão dos interesses públicos tutelados pela Administração.” (DI PIETRO, 2007, p. 68)

Outro ponto que merece destaque é que a competência discricionária não é fruto do esquecimento do legislador. Ao contrário, a discricionariedade surge a partir da outorga legislativa explícita ou implícita. (MELLO, 2011, p. 970)

Trata-se, portanto, de competência a ser exercida de maneira legalmente condicionada, ou seja, quando, conforme e nos estreitos limites e possibilidades da outorga legal.

Torna-se assim imperioso não confundir o ato discricionário com o ato arbitrário. Aquele é praticado pelo agente público competente e se caracteriza pela escolha de uma entre várias soluções legalmente admitidas. Em sentido diametralmente oposto, a atuação arbitrária viola os parâmetros legais e jurídicos, constituindo-se em ato ilícito. (GASPARINI, 2009, p. 98) 


\title{
O EXERCÍCIO DA DISCRICIONARIEDADE ADMINISTRATIVA NO CONTEXTO DO ESTADO SOCIAL E DEMOCRÁTICO DE DIREITO: LIMITES E POSSIBILIDADES A PARTIR DA CONSTITUIÇÃO FEDERAL DE 1988
}

Ainda sobre o tema, Maria Sylvia Zanella Di Pietro (2007, p. 20) observa que o ato arbitrário não é necessariamente um ato injusto, mas sempre será um ato ilícito, porquanto praticado contra ou além da lei.

Desta forma, a solução discricionária deve alinhar-se dentre aquelas juridicamente admitidas. Por mais que o agente público entenda que outra medida confira resposta mais adequada e eficiente em face do problema vivenciado, não lhe é dado praticá-la, sob pena de violação do sistema de tripartição de poderes e do próprio Estado de Direito.

Todavia, vale aqui lembrar que, como afirma Maria Sylvia Zanella Di Pietro (2007, p. 75-76), dentre outras hipóteses que serão abaixo analisadas, a discricionariedade administrativa pode surgir quando a lei (o texto legislado) é insuficiente e não prevê todas as possibilidades supervenientes à sua promulgação ou quando prevê determinada competência e não estabelece a conduta a ser adotada, hipóteses em que o agente público deve atuar e buscar soluções adequadas com base nos princípios jurídicos

Trata-se, sem dúvidas, de caso de lacuna legal e da irrefutável necessidade de integração jurídica. Como se sabe, por mais que o legislador seja previdente no cumprimento da sua atribuição constitucional de elaborar leis, a dinâmica social e a própria limitação da mente humana fazem como que, não raras vezes, o texto legislado deixe de oferecer regras suficientes para o deslinde de alguns casos concretos, notadamente daqueles casos difíceis.

Na sua atividade de aplicação da lei, o administrador público não pode deixar de dar solução aos problemas cotidianos e, por isso, deve buscar no Direito - notadamente nos princípios jurídicos - a adequada solução jurídica para o caso que se põe à sua análise.

Discorrendo sobre o tema, Maria Sylvia Zanella Di Pietro (2007, p. 171) enfatiza que

\begin{abstract}
No processo de integração do direito administrativo os princípios gerais de direito têm relevância, devendo ser invocados, em caso de omissão da lei. Da mesma forma que o juiz, a autoridade administrativa não pode deixar de resolver os casos concretos de sua competência. Mesmo porque a omissão da Administração Pública dá ensejo à propositura de ação judicial.
\end{abstract}

Não se deve, de outro lado, confundir a omissão legislativa com o intento do legislador de não abranger a hipótese dentro do espectro da regulamentação legal. No primeiro caso, o administrador público poderá socorrer-se da analogia, dos costumes e dos princípios gerais de direito para a integração legal; enquanto isto, na segunda hipótese, não lhe é lícito lançar mão de tais ferramentas, sob pena de tornar-se um legislador positivo e, com isso, exercer funções que não lhe são conferidas no Estado Social e Democrático de Direito. 
Assim, conclui-se que a discricionariedade administrativa é um dever-poder jurídico conferido explícita ou implicitamente pelo legislador ao administrador público para que, dentro dos limites da outorga legal e com estreita observância dos princípios constitucionais e legais, delibere fundamentada e motivadamente, segundo critérios de razoabilidade socialmente aceitos, acerca da decisão oportuna e conveniente para a solução de determinado caso concreto que se lhe apresente.

\section{CRITÉRIOS DE IDENTIFICAÇÃO DA DISCRICIONARIEDADE ADMINISTRATIVA}

Para que possa atuar de maneira conforme ao Direito e à lei, o administrador público precisa identificar se a competência que lhe é deferida pelo legislador é de natureza vinculada ou discricionária.

A análise do modal deôntico do tipo legal, ou seja, do próprio texto legislativo é a primeira forma de identificar se a competência deferida pela lei ao administrador público é de natureza vinculada ou discricionária.

Nesse sentido, Diógenes Gasparini (2009, p. 97) esclarece que a competência vinculada é expressa no enunciado legal através de expressões como "será concedido, será outorgado, ou outra da mesma índole."; de outro lado, leciona que, na competência discricionária, “[...] a hipótese legal incumbe-se, em princípio, de indicar quando é possível essa atuação por meio das expressões: será facultado, poderá o Poder Público, ou outra da mesma natureza." (2009, p. 98)

Por seu turno, Celso Antônio Bandeira de Mello (2011, p. 976) ensina que a discricionariedade pode resultar da hipótese da norma jurídica, do seu mandamento ou da sua finalidade.

Decorrerá a discricionariedade da hipótese legal quando os pressupostos fáticos descritos na norma como autorizadores ou exigentes de dado comportamento administrativo são representados por palavras ou locuções plurissignificativas, representantes de conceitos práticos, “[...] incumbindo à Administração determinar-lhes concretamente o alcance na espécie.” (MELLO, 2011, p. 976)

Da mesma maneira, a discricionariedade deitará suas raízes na finalidade legal quando esta também for definida através de termos plurissignificativos, a exemplo do que acontece com 


\section{O EXERCÍCIO DA DISCRICIONARIEDADE ADMINISTRATIVA NO CONTEXTO DO ESTADO SOCIAL E DEMOCRÁTICO DE DIREITO: LIMITES E POSSIBILIDADES A PARTIR DA CONSTITUIÇÃO FEDERAL DE 1988}

a proibição ou determinação desta ou daquela conduta com o fim de preservar a moralidade pública (MELLO, 2011, p. 978) ou, no contexto deste trabalho, para a preservação da segurança viária.

E, finalmente, a discricionariedade poderá decorrer do mandamento legal quando, diante de determinado fato administrativo, a lei faculta um comportamento ao invés de exigi-lo ou então quando confere ao administrador a incumbência de decidir entre duas ou mais alternativas previstas no texto legislativo (MELLO, 2011, p. 980). É o que ocorre, v.g., com a possibilidade de substituição da retenção do veículo pelo recolhimento do seu certificado de licenciamento anual, conforme prescrito no $\$ 2^{\circ}$ do art. 270 do Código de Trânsito Brasileiro.

Seguindo a mesma trilha, Maria Sylvia Zanella Di Pietro (2007, p. 117) conclui que a discricionariedade administrativa pode situar-se tanto na hipótese como no mandamento da norma, de maneira que

[...] a discricionariedade está na hipótese da norma quando os pressupostos de fato por ela enunciados (motivos do ato administrativo) são descritos mediante os chamados conceitos práticos, ou seja, determinados por meio de palavras vagas, imprecisas, como pobreza e notável saber. A discricionariedade está no mandamento quando a norma facultar um comportamento, ao invés de exigi-lo.

Seja de qual forma for o uso de conceitos jurídicos indeterminados no tipo legal, seja para expressar conceitos de experiência ou de valor, exige que o aplicador da lei opte, segundo critérios de razoabilidade e de adequação social, por um dos vários sentidos possíveis. Em nenhum dos casos o administrador público pode definir o sentido do termo legal plurissignificativo segundo os seus critérios e valores pessoais, o que afrontaria o perfil democrático do múnus publico que exerce.

Perfilando este entendimento, Eros Roberto Grau (2006, p. 97-98) ensina que

$\mathrm{O}$ objeto do conceito jurídico não existe 'em si mesmo'; dele não há uma representação concreta, nem mesmo gráfica. Tal objeto só existe 'para mim', de modo tal, porém, que sua existência abstrata apenas tem validade, no mundo jurídico, quando a este 'para mim, por força de convenção normativa, corresponde um - sejame permitida a expressão - 'para nós'.

Desta feita, a abertura do conceito jurídico indeterminado não permite que o administrador público lhe confira sentido e concretude segundo os seus próprios princípios ou valores. Ao contrário, é imperioso que encontre um sentido razoável e socialmente aceito segundo os valores e princípios da sociedade em que está inserido, o que denota ainda a característica de mutabilidade do conceito, ou seja, a sua possibilidade de variar no tempo e no espaço. 
Entretanto, o emprego de fórmulas amplas nem sempre indicam a existência de discricionariedade do administrador público para a prática de determinado ato, vez que a realidade fenomênica pode conduzir a uma única possibilidade de interpretação e, consequentemente, à vinculação da atuação administrativa. Trata-se do que se distingue como discricionariedade na norma e discricionariedade no fato concreto, o que será objeto de maiores reflexões no tópico seguinte.

Outro ponto relevante diz respeito às relações que permeiam entre interpretação legal e discricionariedade. Para Maria Sylvia Zanella Di Pietro (2007, p. 121), “[...] a autoridade administrativa deve utilizar todos os métodos possíveis de exegese para alcançar o interesse público que o legislador quis proteger ao conferir-lhe discricionariedade. Esta começa onde termina a interpretação."

Já foi dito que não é possível aplicar a lei sem antes interpretá-la e que só após a escorreita exegese é que se saberá qual é o comando normativo que emana do conjunto linguístico que compõe o enunciado legal. E somente após a definição do comando normativo é que se saberá se a competência deferida pelo legislador ao administrador público é de natureza vinculada ou discricionária e, neste caso, quais são suas possibilidades e limites.

E nem se diga que não é deferido ao administrador público a autoridade de interpretar a lei, posto que

\begin{abstract}
Não obstante a exclusividade do Judiciário para decidir, em última instância, sobre a correta interpretação da lei, o Poder Executivo, ou melhor dizendo, a Administração Pública, também tem que aplicar a lei e, antes disso, quando for o caso, fazer a sua interpretação ou integração; a diferença está em que sua decisão é sempre passível de revisão judicial. (DI PIETRO, 2007, p. 156-157)
\end{abstract}

Ao contrário, a intepretação da lei é uma exigência indeclinável para a sua adequada e constitucionalmente ajustada aplicação. Nesse sentido, Fábio Medina Osório (2011, p. 207) aponta que

[...] às autoridades encarregadas de aplicação das normas de Direito Administrativo Sancionador é possível restringir a dureza das leis abstratas, interpretando-as em conformidade com a ordem constitucional. Decorre tal possibilidade do princípio da unidade da ordem jurídica, sendo a Constituição o contexto superior. Daí que a interpretação conforme a constituição configura uma subdivisão da interpretação sistemática.

É, pois, necessário que o administrador público, antes de aplicar a lei ao caso concreto, procure, à luz de uma interpretação sistemática e tópico-dialética, assim entendida aquela que busca o sentido de um preceito normativo a partir da relação que vigora entre o caso concreto, o enunciado legislativo e o Direito como um todo, definir a sua real significação. 
E aqui situa-se outro ponto de fundamental importância no que se refere à discricionariedade: os parâmetros constitucionais e legais para o exercício discricionário.

\section{PARÂMETROS CONSTITUCIONAIS E LEGAIS PARA O EXERCÍCIO DA AÇÃO DISCRICIONÁRIA}

Após reconhecer a competência discricionária que lhe é outorgada pela lei, o administrador público deverá atentar para que o exercício concreto da sua ação discricionária se realize com respeito aos princípios e regras constitucionais, legais e institucionais.

A competência discricionária é conferida ao administrador para que possa, diante de cada caso concreto, com suas características e peculiaridades próprias, encontrar a melhor solução possível, assim entendida aquela que, com respeito às possibilidades e limites constitucionais e legais, garanta o interesse público com o mínimo de afetação aos direitos individuais.

Sob o império do Estado Social e Democrático de Direito não se admite mais a supremacia do indivíduo sobre o grupo e nem a do grupo sobre o indivíduo. A sociedade contemporânea pretende ser pluralista e, assentada sobre o valor da dignidade da pessoa humana, reconhece a indissociabilidade da relação indivíduo-sociedade e sociedade-indivíduo como pressuposto para a efetivação da democracia e dos direitos fundamentais.

O encontro desta justa medida entre o interesse público e o interesse individual é o que se espera do exercício discricionário do administrador público. Antes de prosseguir, é importante registrar que o interesse individual aqui referido não é a vontade egoística e mesquinha da pessoa, que, enclausurada no seu próprio mundo, desconhece e desrespeita todos os que a cercam. Bem diferente, o interesse individual merecedor da tutela administrativa é aquele representado pelos direitos fundamentais, que encontram no princípio da dignidade humana $\left(\mathrm{CF} / 88\right.$, art. $1^{\circ}$, III) o seu epicentro axiológico.

Destarte, pode-se afirmar que o primeiro ponto a ser revisitado para o escorreito exercício discricionário na sociedade contemporânea é o princípio da supremacia do interesse público sobre o interesse particular.

Recorda Fábio Medina Osório que “[...] a base de toda a formação teórica do Direito Administrativo é o conceito de interesse público" (2011, p. 66). Entretanto, reconhece que “[...] 
o embasamento do Direito Administrativo no interesse público é, a um só tempo, verdadeiro e paradoxalmente vazio" (2011, p. 68).

Desde logo é de ser observado que não se deve confundir interesse público com interesse da administração pública, embora em alguns casos possam, e no demais das vezes deveriam, ser coincidentes.

Conforme leciona Luís Roberto Barroso (2005, p. 513), o interesse público primário é representado por valores como justiça, segurança jurídica e bem-estar social e o interesse público secundário é o interesse da Fazenda Pública, do erário, de arrecadação de recursos, com o que conclui pela "[...] superação do denominado princípio da supremacia do interesse público sobre o particular, substituído pelo princípio da ponderação de direitos fundamentais."

Na linha desse raciocínio, Maria Sylvia Zanella Di Pietro (2007, p. 223) conclui que “[...] o interesse público primário deve prevalecer sobre o interesse público secundário.”

Esclarecendo as relações entre o interesse público e o privado, Juarez Freitas (2010, p. 257) leciona que "[...] a especificidade do princípio do interesse público está em prescrever que, em caso de colisão, deve preponderar a vontade geral legítima sobre a vontade [individual] egoisticamente articulada", de forma que não se pode invocar o princípio da supremacia do interesse público como uma porta aberta para o “[...] arbitrário e inaceitável jugo da vontade do particular imolado para gáudio de volúvel e falso interesse coletivo.”

E é exatamente para realizar a ponderação entre interesse público e interesse individual na busca da ótima solução para o caso concreto que o legislador confere o dever-poder do exercício discricionário ao administrador público. A discricionariedade não é simplesmente um poder do administrador público, mas, muito antes, um dever que lhe é imposto para encontrar, dentro dos limites constitucionais e legais, a melhor solução para o caso que se põe à sua frente, realizando assim a justa medida entre o interesse público e o interesse individual.

Ao conferir ao administrador público o dever-poder do exercício discricionário, o legislador reconheceu a insuficiência da previsão legal de uma solução-padrão para a escorreita decisão dos problemas que cotidianamente se multiplicam na dinâmica e multifacetária realidade social. E sobre esta insuficiência da lei para a solução dos problemas cotidianos, Fábio Medina Osório (2011, p. 38) observa que os

[...] dispositivos editados abstratamente pelo Poder Legislativo, tiveram sua real utilidade muito reduzida. Tais instrumentos são meras referências abstratas, embora possam, em algumas oportunidades, abarcar e esgotar problemas dóceis. Os problemas perversos demandam raciocínios sofisticados, à altura da complexidade das decisões normativas que englobam múltiplos elementos.

Rev. Brasileira de Filosofia do Direito | e-ISSN: 2526-012X | Brasília | v. 3 | n. 1 | p. 133-152 | Jan/Jun. 2017 


\section{O EXERCÍCIO DA DISCRICIONARIEDADE ADMINISTRATIVA NO CONTEXTO DO ESTADO SOCIAL E DEMOCRÁTICO DE DIREITO: LIMITES E POSSIBILIDADES A PARTIR DA CONSTITUIÇÃO FEDERAL DE 1988}

Neste árduo caminho pela busca da ótima solução do caso concreto, o administrador público deverá guiar-se pelos princípios e valores constitucionais e legais, realizando um exercício de ponderação e argumentação motivada.

E, neste momento, vale lembrar o sempre exaltado ensinamento de Celso Antônio Bandeira de Mello (2011, p. 967) de que a violação de um princípio é a mais grave de todas as irresignações jurídicas.

Neste contexto, não há como esquecer que no centro desta rede de princípios está o princípio da dignidade da pessoa humana e, consequentemente, toda a gama de direitos fundamentais que lhe são correlatos, que, portanto, devem figurar no centro das decisões administrativas discricionárias, notadamente em razão do seu caráter vinculativo para os órgãos estatais dos três Poderes (eficácia vertical dos direitos fundamentais).

Não se trata, portanto, o exercício discricionário de uma escolha livre e desimpedida do administrador, embora possa assim ser entendido por alguns que, apressada e inadvertidamente, concluem que a discricionariedade se confunde com a arbitrariedade.

Vinculando a escolha discricionária à formulação de um juízo fundado em princípios e valores próprios da sociedade em que se está inserido e não simplesmente do juízo subjetivo e pessoal do administrador público, Maria Sylvia Zanella Di Pietro (2007, p. 104) leciona que

[...] a possibilidade de apreciação subjetiva não é ilimitada, porque o administrador público, ao aplicar a lei, não pode afastar-se das concepções sociais dominantes; se ele decidir de forma contrária a essa concepção, é porque teve a intenção de abandonar a apreciação técnica ou incidir em erro grosseiro-

Com efeito, nem todas as possibilidades decisórias coincidem com a ótima solução do caso concreto. O leque de soluções ofertadas ao administrador público restringe-se diante das características e peculiaridades da situação real que se põe ao seu deslinde.

Não raras vezes, a discricionariedade concreta não abarca o mesmo espectro de possibilidades que aquela prevista abstratamente na lei. Sintetizando este entendimento, Celso Antônio Bandeira de Mello (2011, p. 971) registra que

\footnotetext{
A existência de discricionariedade ao nível da norma não significa, pois, que a discricionariedade existirá com a mesma amplitude perante o caso concreto e nem sequer que existirá em face de qualquer situação que ocorra, pois a compostura do caso concreto excluirá obrigatoriamente algumas das soluções admitidas in abstracto na regra e, eventualmente, tornará evidente que uma única medida seria apta a cumprir-lhe a finalidade. Em suma, a discrição suposta na regra de Direito é condição necessária, mas não suficiente, para que exista discrição no caso concreto; vale dizer, na lei se instaura uma possibilidade de discrição, mas não uma certeza de que existirá em todo e qualquer caso abrangido pela dicção da regra.
} 
Há, portanto, situações em que o senso comum indica que, dentre todas as medidas administrativas possíveis, apenas uma delas é apta para representar a ótima solução do caso concreto. Caso o administrador público se desvie desta medida, sua decisão estará sujeita à correção administrativa ou judicial.

Assim sendo, no exercício da discricionariedade administrativa, o administrador público não deve olvidar do princípio da proporcionalidade, que, conforme leciona Paulo Bonavides (2001, p. 396), está implicitamente assentado na Constituição Federal de 1988.

Além da sua previsão constitucional implícita, o princípio da proporcionalidade encontra prescrição no parágrafo único do art. $2^{\circ}$ da Lei $n^{\circ} 9.784 / 99$, que impõe à atuação administrativa a adequação entre meios e fins, sendo vedada a imposição de obrigações, restrições e sanções em medida superior àquelas estritamente necessárias ao atendimento do interesse público.

No âmbito do Estado de São Paulo, a razoabilidade está expressamente prevista no art. 111 da Constituição Estadual como um dos princípios que deve nortear a atuação da Administração Pública paulista.

O princípio da proporcionalidade pode ser sintetizado na “[...] relação adequada entre um ou vários fins determinados e os meios com que são levados a cabo" (BONAVIDES, 2001, p. 357) e, conforme observa Fábio Medina Osório (2011, p. 187), merece especial destaque no âmbito do Direito Público e, muito especialmente,

[...] no manejo de sanções que atingem direitos fundamentais, normas de Direito Administrativo, que tipificam e sancionam categorias de atos ilícitos, [...], seja na adequação típica das condutas às descrições das normas, seja na atenuação dos rigores sancionatórios abstratos, podendo ser efetuada uma correção de intoleráveis distorções legislativas."

Através do princípio da proporcionalidade, o administrador público pode, na situação concreta, promover o necessário "[...] equilíbrio entre os direitos individuais atingidos pelos instrumentos administrativos repressores e os direitos da comunidade protegidos pelo mesmo legislador" (OSÓRIO, 2011, p. 188), efetivando assim a justa medida entre o interesse público e o interesse individual.

Com o princípio da proporcionalidade caminham os preceitos da vedação do excesso e da proibição de omissão estatal. Desta feita, o administrador público

[...] não deve agir com demasia, tampouco de modo omisso ou inoperante na consecução dos seus objetivos. Exageros (para mais ou para menos) configuram violações ao princípio. Na primeira situação, ocorre ofensa à vedação do excesso, na tríplice dimensão de necessidade, adequação e proporcionalidade em sentido estrito 
[razoabilidade]. Na segunda faceta, tem-se a inoperância do Estado no cumprimento dos seus deveres. (FREITAS, 2010, p. 257-258)

Se é correto afirmar que a decisão discricionária deve alinhar-se entre as soluções juridicamente permitidas, também é certo que, dentre todas elas, o administrador público deve escolher aquela que se mostre necessária, adequada e suficiente para proteger o interesse público tutelado pela norma e, ao mesmo tempo, resvalar o mínimo possível nos interesses individuais, notadamente quando estes se caracterizam como direitos fundamentais.

O excesso e omissão do administrador público no exercício da atividade discricionária poderão ser objeto de apreciação judicial e, em ambos os casos, além de infração administrativa, "[...] havendo nexo causal direto e imediato (primeiro requisito) e dano injusto (segundo requisito), seguirá o dever de indenizar e o ônus da prova da não configuração do nexo causal incumbirá ao Poder Público.” (FREITAS, 2010, p. 258)

Portanto, como decorrência do princípio da proporcionalidade no exercício da atividade discricionária, o administrador público deve deixar evidentes as razões fáticas e jurídicas que lhe levaram a esta ou aquela solução, o que consubstancia a motivação idônea do ato administrativo e permite a aferição administrativa e/ou judicial da sua conduta.

Seguindo esse raciocínio, Fábio Medina Osório (2011, p. 191) denuncia a imperiosidade de que as decisões administrativas sejam repletas de "ponderações e raciocínios fundamentados” e Maria Sylvia Zanella Di Pietro (2007, p. 207) anota ser “[...] imprescindível, para avaliação da razoabilidade [proporcionalidade em sentido estrito], conhecer os motivos que levaram a administração a adotar determinada medida (objeto do ato administrativo) para alcançar a finalidade que decorre implícita ou explicitamente da lei.”

Destarte, não basta que o ato praticado no exercício da competência discricionária se enquadre nos limites legais para que mereça a tutela do Direito, posto que, assim sendo, “[...] embora esteja aparentemente de acordo com a lei e nos limites da discricionariedade, contraria, inteiramente e de forma manifesta, o senso comum do que é certo, justo, adequado e consentâneo com o interesse público.” (DI PIETRO, 2007, p. 203)

Daí porque se mostra indeclinável que a passagem da regra abstrata prevista na lei para a aplicação concreta das normas jurídicas se faça, seja na via administrativa ou judicial, através de processos interpretativos fundamentados e elaborados a partir de

[...] valorações, ponderações, subjetividades, enfatizando, explícita ou implicitamente, as distinções entre textos e normas, estas nas perspectivas de regras ou princípios, tudo à luz das teorias argumentativas que evidenciam o Direito movido a razões, calcadas na hermenêutica jurídica. (OSÓRIO, 2001, p. 39) 
Pode-se assim afirmar que, no exercício da competência discricionária, o administrador público deve, através da concatenação tópico-sistemática e dialética entre o fato concreto e os princípios, valores e regras jurídicas que lhe dão disciplina, buscar a melhor solução possível, que, por óbvio, nem sempre será a mesma em todas as situações que se apresentam no cotidiano administrativo.

Não se trata, evidentemente, de uma violação do princípio da igualdade e nem ao da impessoalidade. Ao contrário, o princípio da igualdade, em seu viés concreto ou material, exige que o administrador público tenha em consideração as desigualdades existentes no mundo real no momento da sua tomada de decisão discricionária, de modo que dê soluções iguais para situações iguais e soluções desiguais para situações desiguais. Tal procedimento não nega a isonomia constitucional, mas, muito antes, a realiza.

Admitindo as discriminações levadas a efeito pelo administrador público, Celso Antônio Bandeira de Mello (2011, p. 192) explica que

[...] são recebidas como compatíveis com a cláusula igualitária apenas e tão-somente quando existe um vínculo de correlação lógica entre a peculiaridade diferencial acolhida por residente no objeto, e a desigualdade de tratamento em função dela conferida.

Assim sendo, não se poderá alcunhar de arbitrária ou discriminatória, em seu sentido negativo, a decisão discricionária que, fundando-se em critérios distintivos acolhidos pela lei e pelo Direito, conferir soluções diferentes no ato de aplicação concreta da lei.

Como já se disse, a competência discricionária é outorgada pelo legislador ao administrador público justamente para que possa encontrar, dentre todas aquelas permitidas pela lei e pelo Direito, a ótima solução para o caso concreto, dentro de um critério de razoabilidade e de ponderação entre o interesse público e o interesse individual em jogo. E, como soa lógico, o escorreito exercício da competência discricionária outorgada pela lei não pode ser considerado uma violação do princípio da igualdade ou da impessoalidade.

A distinção na solução discricionária não se dá em face desta ou daquela pessoa, mas, diferentemente, em razão de situações que ora se assemelham e ora se distinguem.

Perfilando este entendimento, Celso Antônio Bandeira de Mello (2011, p. 971) observa que

[...] a variedade de soluções comportadas na regra outorgadora de discrição não significa que todas estas soluções sejam igual e indiferentemente adequadas para todos os casos de sua aplicação. Significa, pelo contrário, que a lei considera que algumas delas são adequadas para certos casos e outras para outros casos. 


\section{O EXERCÍCIO DA DISCRICIONARIEDADE ADMINISTRATIVA NO CONTEXTO DO ESTADO SOCIAL E DEMOCRÁTICO DE DIREITO: LIMITES E POSSIBILIDADES A PARTIR DA CONSTITUIÇÃO FEDERAL DE 1988}

Vê-se, com tudo que foi exposto, que a escolha discricionária razoável e adequada não é tarefa das mais fáceis, notadamente quando se está diante de situações difíceis que demandam uma reflexão mais complexa e que, muitas vezes, decorrem de uma intrincada compreensão das relações que permeiam entre princípios, valores e regras.

\section{CONSIDERAÇÕES FINAIS}

A dinamicidade da sociedade contemporânea, complexa e plural, exige que o Estado seja ágil e eficaz nas suas ações, de modo a garantir o atendimento das múltiplas necessidades sociais e individuais.

Se, por um lado, não se pode admitir que o administrador público exerça o seu ofício segundo os seus critérios pessoais; de outro, é igualmente inadmissível que as balizas da legalidade sejam tão estreitas que não lhe permita qualquer margem de conformação da sua atuação administrativa.

Encontrar o ponto de equilíbrio é requisito indeclinável para a atuação administrativa consentânea com os ditames do Estado Social e Democrático de Direito, mormente no que diz respeito à proteção e promoção da dignidade humana e dos direitos fundamentais que lhe são correlatos.

O administrador público contemporâneo não pode se esconder atrás do cômodo discurso do princípio da estrita legalidade para justificar sua atuação descomprometida com a realização dos valores albergados sob o manto constitucional.

Se o Estado é o grande vilão dos direitos fundamentais, isto muito se deve à equivocada compreensão do princípio da legalidade na atual quadra histórica. Atualmente, não é mais crível olvidar que a Constituição repousa soberana na estrutura do ordenamento jurídico e que as leis são instrumentos de aproximação da vontade constitucional da realidade cotidiana, extraindo seu pressuposto de validade material no respeito aos valores que são por ela sufragados.

O princípio da legalidade ganha contornos de princípio da juridicidade e o administrador público deve se guiar não mais apenas na letra da lei, mas, indo muito além, deve buscar em cada ato administrativo a maior realização possível dos direitos fundamentais afetados. 
Evidentemente que esta tarefa não é nada fácil, especialmente quando se está diante de casos difíceis e a decisão administrativa precisa ser tomada com agilidade, longe da tranquilidade e conforto dos gabinetes.

Seja como for, diante das situações mais simples ou das mais complexas, o administrador público deve adotar suas decisões dentro do espaço discricionário que lhe foi juridicamente conferido, atento às peculiaridades de cada caso concreto e sempre orientado pela busca permanente dos valores supremos consagrados na Constituição Federal, motivando idoneamente a escolha realizada.

\section{REFERÊNCIAS}

BARROSO, Luis Roberto. Temas de Direito Constitucional. Tomo III. Rio de Janeiro: Renovar, 2005.

BONAVIDES, Paulo. Curso de Direito Constitucional. 10. ed. São Paulo: Malheiros, 2001.

DI PIETRO, Maria Sylvia Zanella. Discricionariedade Administrativa na Constituição de 1988. 2.ed. São Paulo: Atlas, 2007.

FERREIRA FILHO, Manoel Gonçalves. Direitos humanos fundamentais. 8.ed. rev. e atual. São Paulo: Saraiva, 2006.

FREITAS, Juarez. A interpretação Sistemática do Direito. 5.ed. São Paulo: Malheiros, 2010.

GASPARINI, Diógenes. Direito Administrativo. 14.ed. rev. São Paulo: Saraiva, 2009.

GRAU, Eros Roberto. Ensaio e discurso sobre a interpretação/aplicação do direito. 4.ed. São Paulo: Malheiros, 2006.

MEDAUAR, Odete. Direito Administrativo Moderno. 5.ed. rev. e atual. São Paulo: Revista dos Tribunais, 2001.

MELLO, Celso Antônio Bandeira de. Curso de Direito Administrativo. 28 ed. rev. e atual. São Paulo: Malheiros, 2011.

OSÓRIO, Fábio Medina. Direito Administrativo Sancionador. 4. ed. rev. atual. e ampl. São Paulo: Revista dos Tribunais, 2011.

SARLET, Ingo Wolfgang. A eficácia dos direitos fundamentais. 8.ed. rev. e atual. Porto Alegre: Livraria do Advogado, 2007. 